\title{
TGF-B signaling is required for maintenance of retinal ganglion cell differentiation and survival
}

\section{Citation}

Walshe, T.E., L.L. Leach, and P.A. D'Amore. 2011. “TGF-B Signaling Is Required for Maintenance of Retinal Ganglion Cell Differentiation and Survival." Neuroscience 189 (August): 123-131. doi:10.1016/j.neuroscience.2011.05.020.

\section{Published Version}

doi:10.1016/j.neuroscience.2011.05.020

\section{Permanent link}

http://nrs.harvard.edu/urn-3:HUL.InstRepos:34854258

\section{Terms of Use}

This article was downloaded from Harvard University's DASH repository, and is made available under the terms and conditions applicable to Other Posted Material, as set forth at http:// nrs.harvard.edu/urn-3:HUL.InstRepos:dash.current.terms-of-use\#LAA

\section{Share Your Story}

The Harvard community has made this article openly available.

Please share how this access benefits you. Submit a story.

Accessibility 


\title{
TGF- $\beta$ signaling is required for maintenance of retinal ganglion cell differentiation and survival
}

\author{
Tony E. Walshe ${ }^{1,{ }^{*}, \text { Lyndsay L. Leach }}{ }^{1,{ }^{*}}$, and Patricia A. D’Amore ${ }^{1}$ \\ Tony E. Walshe: tony.walshe@schepens.harvard.edu; Lyndsay L. Leach: lyndsay.leach@lifesci.ucsb.edu \\ ${ }^{1}$ Departments of Ophthalmology and Pathology, Harvard Medical School, Schepens Eye \\ Research Institute, 20 Staniford Street, Boston, MA f02114, USA
}

\section{Abstract}

Purpose-To determine the role of TGF- $\beta 1$ in the maintenance of retinal ganglion cell line (RGC-5) differentiation and integrity.

Methods-RGC- 5 cells were differentiated in media conditioned by human non-pigmented ciliary epithelial cells (HNPE) for four days before treatment with TGF- $\beta 1$ for $24 \mathrm{hr}$. Cells were examined for morphological changes and harvested for western blot and real-time PCR analysis. For study of apoptosis, differentiated RGC-5 cells were grown in serum-free medium for $24 \mathrm{hr}$ in the presence or absence of TGF- $\beta 1$ and collected for Annexin V/Propidium iodide FACs analysis. The role of MAPK pathways in TGF- $\beta 1$-dependent signaling was determined by treatment with specific inhibitors of ERK, JNK and p38.

Results-Differentiation of RGC-5 cells in HNPE-conditioned media (CM) increased the neural cell markers, Brn-3c, NF-160, Thy1.2, Tau and PGP9.5. Treatment with TGF- $\beta 1$ significantly increased the length of neurites extended by differentiated RGC-5s, concomitant with increased expression of NF-160 and PGP9.5, but not Brn-3c, Thy 1.2 or Tau. TGF- $\beta 1$ also decreased RGC-5 cell apoptosis in serum-free medium. p38 phosphorylation, but not smad2/3, JNK or ERK phosphorylation, was increased in TGF- $\beta 1$ treated cells. Specific inhibition of p38 signaling reversed TGF- $\beta 1$ induced neurite growth.

Conclusions-These findings demonstrate the induction of RGC-5 cell differentiation by HNPE derived CM and illustrate a role for TGF- $\beta 1$ in maintaining RGC-5 cell survival and promoting neurite outgrowth through $\mathrm{p} 38$ MAPK.

\section{Keywords}

TGF- $\beta 1$; retina; neurite; differentiation; apoptosis; $\mathrm{p} 38$

RGCs are highly specialized cells of the central nervous system situated in the inner layer of the retina. RGCs receive visual information from the photoreceptors of the outer retina via amacrine and bipolar cells and relay it to the brain. Raised intraocular pressure in glaucomatous patients is thought to target RGCs and their axons, particularly at the optic

\footnotetext{
(C) 2011 IBRO. Published by Elsevier Ltd. All rights reserved.

Corresponding author: Patricia A. D’Amore, tel: 1-617-912-2559, fax: 1-617-912-0128, patricia.damore@ schepens.harvard.edu; Schepens Eye Research Institute, 20 Staniford Street, Boston, MA 02114, USA.

contributed equally
}

Publisher's Disclaimer: This is a PDF file of an unedited manuscript that has been accepted for publication. As a service to our customers we are providing this early version of the manuscript. The manuscript will undergo copyediting, typesetting, and review of the resulting proof before it is published in its final citable form. Please note that during the production process errors may be discovered which could affect the content, and all legal disclaimers that apply to the journal pertain. 
nerve head where damage is evidenced by cupping and distension of the lamina cribrosa plates occurs (Downs et al., 2008).

We have previously demonstrated that systemic neutralization of TGF- $\beta$ in the adult mouse via expression of soluble endoglin (sEng), a TGF- $\beta$ inhibitor, results in impaired visual acuity as detected by electroretinogram (ERG) recordings. sEng-expressing mice had impaired vascular perfusion and increased retinal vascular permeability, as well as RGC apoptosis as detected by TEM and TUNEL staining (Walshe et al., 2009). These studies did not determine whether RGC cell death and dysfunction were a reflection of neuroprotective properties of TGF- $\beta$ on RGCs or a secondary effect of vascular dysfunction.

Ganglion cells of the developing postnatal mouse and rat retina express both TGF- $\beta 1$ ligand and TGF $\beta R 2$, and TGF $\beta R 2$ is detected in the body and axons of adult ganglion cells, suggesting a non-redundant role for TGF- $\beta$ signaling in RGCs (Gordon-Thomson et al., 1998, Guérin et al., 2001, Close et al., 2005). Smad transcription factors, classical members of a family of transcription factors that are phosphorylated and mediate the TGF- $\beta 1$ response in numerous cell types, are expressed by RGCs in vivo (Walshe et al., 2009). Another network of interacting proteins that regulates a large number of cellular processes, the MAPKs, also mediate communication of extracellular signals into intracellular targets. The MAPK cascade is comprised of three main signaling pathways, ERK, JNK and p38. Each of these signal in RGCs and are known to mediate TGF- $\beta 1$ signaling in other cell types (Watanabe et al., 2001, Goldberg et al., 2002, Dhandapani et al., 2003, Rodríguez-Barbero et al., 2006).

In this study, we examined the potential neuroprotective role of TGF- $\beta 1$ for RGC- 5 cells and its effects on neurite outgrowth in vitro. We also characterized the role of the smad and MAPK pathways in mediating the effects of TGF- $\beta 1$ on RGC- 5 cell differentiation. Identifying and understanding the role of neuroprotective factors for RGC-5 cells is of particular relevance for conditions characterized by RGC degeneration, such as glaucoma (Bode et al., 2011) or multiple sclerosis (Green et al., 2010).

\section{Experimental Procedures}

\section{RGC- 5 cell culture and differentiation}

The RGC-5 cell line was developed as a retinal ganglion cell line by transformation of retinal cells; these cells have the characteristics of RGC based on Thy-1 and Brn-3C expression (Krishnamoorthy et al., 2001). RGC-5 cells were grown in Dulbecco's modified Eagle's medium (DMEM; Invitrogen-GIBCO, Grand Island, NY), supplemented with 10\% heat-inactivated fetal bovine serum (Atlanta Biologicals, Inc., Lawrenceville, GA), 100 U/ $\mathrm{ml}$ penicillin, and $100 \mu \mathrm{g} / \mathrm{ml}$ streptomycin. RGC- 5 cells were differentiated by adding media conditioned by HNPE cells (Tchedre et al., 2008b, Tchedre and Yorio, 2008). For preparation of CM, HNPE cells were grown to $\sim 90 \%$ confluence and incubated for $24 \mathrm{hr}$ with serum-free DMEM. RGC- 5 cells were seeded sparsely at $100 \mathrm{cell} / \mathrm{cm}^{2}$, media was removed $24 \mathrm{hr}$ later and replaced with HNPE-conditioned medium supplemented with $0.2 \%$ heat-inactivated fetal bovine serum. The cells were then incubated at $37^{\circ} \mathrm{C}$ in $5 \% \mathrm{CO}_{2}$ for four days to allow the cells to differentiate.

To assess the possible role of TGF- $\beta 1$ in RGC-5 differentiation, $0.1,1.0$ and $10 \mathrm{ng} / \mathrm{ml} \mathrm{TGF-}$ $\beta 1$ (R\&D Systems, Minneapolis, MN) was added to cells that had been differentiated in HNPE CM. Cells morphology was examined and protein and mRNA analyzed after $24 \mathrm{hr}$ treatment. A neurite was defined as a process that was longer than one cell body (typically $>35-40 \mu \mathrm{m}$ ) (Laketa et al., 2007, Endo et al., 2008). For each treatment, neurite length was 
measured on 10-12 pictures taken at 10X magnification using ImageJ software and data were analyzed using Prism.

\section{Apoptosis assay}

RGC- 5 cells were plated at a density of $\sim 100$ cells $/ \mathrm{cm}^{2}$ on $0.1 \%$ collagen coated flasks and differentiated for four days as described above. To assess the effect of TGF- $\beta 1$ on RGC-5 apoptosis, cells were incubated in $0.1 \mathrm{ng} / \mathrm{ml}$ TGF- $\beta 1$ in serum-free DMEM for $24 \mathrm{hr}$ and apoptotic cells were detected using the Vybrant ${ }^{\circledR}$ Apoptosis Assay Kit (Invitrogen, Carlsbad, CA), followed by FACS analysis using a FACSCAN flow cytometer. Cellular ATP levels were assayed as a surrogate for viable cells using the CellTiter-Glo Luminescent Cell Viability Assay (Promega, Madison, WI) (Du et al., 2009).

\section{SDS-PAGE and immunoblot analysis}

Cell pellets were treated with lysis buffer (Cell Signaling, Danvers, MA) and equal protein was fractionated by $10 \%$ (wt/vol) polyacrylamide resolving gels (Bio-Rad, Hercules, CA). After transfer to nitrocellulose membranes, non-specific protein binding was blocked by a 60-min incubation in TBS-T (Tris-buffered saline, 0.1\% Tween-20) containing 5\% (wt/vol) nonfat skim milk and $2.5 \%$ BSA. Membranes were then incubated at $4{ }^{\circ} \mathrm{C}$ overnight with one of the following antisera: pp-smad2/3 (1:1000; Abcam, Cambridge, MA), smad2/3 (1:1000; Abcam, Cambridge, MA), pp-smad1/5/8 (1:1000; Millipore, Temecula, CA), smad1/5/8 (1:1000; Santa Cruz Biotechnology, Santa Cruz, CA), pp-p38 (1:1000; Cell Signaling, Danvers, MA), p38 (1:1000; Cell Signaling, Danvers, MA), pp-SAPK/JNK (1:1000; Cell Signaling, Danvers, MA), SAPK/JNK (1:1000, Cell Signaling, Danvers, MA), pp-Erk1/2 (1:1000; Cell Signaling, Danvers, MA), Erk1/2 (1:1000; Cell Signaling, Danvers, MA), Brn-3c (1:1000; Abcam, Cambridge, MA), neurofilament-M (NF-160) (1:500; Sigma, St. Louis, MO) or Thy1.2 (1:2000; Abcam, Cambridge, MA) diluted in TBS-T with 2.5\% BSA. After four 6-min washes with TBS-T, membranes were incubated for $60 \mathrm{~min}$ at room temperature with horseradish peroxidase-conjugated rabbit polyclonal or mouse monoclonal IgG antibody (1:5000; GE Healthcare, Fairfield, CT). After four additional washes with TBS-T, immunoreactive proteins were identified by enhanced chemiluminescence. Scanning densitometry was performed with image-analysis software (ImageJ), with values normalized for loading using Ponceau staining for total protein.

To block MAPK signaling pathways, PD169316 (p38 inhibitor) (0.5 $\mu$ M; Sigma, St. Louis, MO), SP600125 (JNK inhibitor) (0.5 $\mu \mathrm{M}$; Sigma, St. Louis, MO), or 3-(2-aminoethyl)-5((4-ethoxyphenyl)methylene)-2,4-thiazolidinedione hydrochloride (ERK inhibitor) $(0.5 \mu \mathrm{M}$; Sigma, St. Louis, MO) were applied $1 \mathrm{hr}$ prior to the addition of $0.1 \mathrm{ng} / \mathrm{ml}$ TGF- $\beta 1$.

\section{RNA isolation and reverse transcription-PCR analysis}

RT-PCR was carried out using total RNA isolated from cells using TRIzol ${ }^{\mathrm{TM}}$ (Invitrogen), according to the manufacturers' specifications. Total RNA (1-2 $\mu \mathrm{g})$ was reverse transcribed to cDNA using iSCRIPT as per the manufacturers' specifications (BioRad). The genespecific oligonucleotide sequences used were: GAPDH: FGGCACAGTCAAGGCTGAGAATG; R-ATGGTGGTGAAGACGCCAGTA; Thy 1.2: FAACTCTTGGCACCATGAACCC; R-GCTGGTCACCTTCTGCCCTC; Tau: FTGAAGACGTGACTGCGCCCCTA; R-CCTGGTTCGGGGTGTCTCCGA; PGP9.5: FGCTTCGCCGACGTGCTAGGG; R-TTTTCATGCTGGGCCGTGAGGG. Reactions were performed on the LightCycler 480II (Roche) using $0.4 \mu \mathrm{M}$ primers and the SYBR Green PCR Master Mix (Applied Biosystems), according to the manufacturer's instructions. Amplification of GAPDH was performed on each sample as a control for normalization. 


\section{Statistical analysis}

Unless otherwise indicated, data are reported as mean \pm SD of at least three independent experiments with three replicates per group. Data were analyzed by student's unpaired T-test using Prism software (and one-way ANOVA). P values $<0.05$ were taken to indicate statistical significance.

\section{Results}

\section{TGF- $\beta 1$ induces neurite outgrowth}

Undifferentiated RGC-5 cells grew rapidly in regular growth medium and appeared as flat cells, with few visible neurite extensions (Fig. 1A). Culture of the cells with HNPE-derived $\mathrm{CM}$ for four days led to differentiation, as evidenced by neurite extension (Fig. 1B). In order to assess the effect of TGF- $\beta 1$ on neurite maintenance or extension, RGC- 5 cells grown in $\mathrm{CM}$ for four days were treated with $0.1,1.0$ or $10 \mathrm{ng} / \mathrm{ml} \mathrm{TGF}-\beta 1$ for $24 \mathrm{hr}$ in CM. Addition of TGF- $\beta 1$ led to increased neurite length, with maximal effect at $0.1 \mathrm{ng} / \mathrm{ml}$ TGF- $\beta 1$ of $\sim 25 \%$ (Fig. 1C and 1D).

\section{TGF- $\beta 1$ modulates RGC- 5 expression of neuronal markers}

Since TGF- $\beta 1$ led to an increase in the extension of neurites by RGC- 5 cells in culture, we sought to determine whether the expression of ganglion cell markers was influenced. Western blot analysis for the transcription factor Brn-3c revealed the absence of expression of Brn-3c in RGC-5 cells not exposed to CM (Fig. 2A). Differentiation of RGC-5 cells for four days led to a significant increase in the level of Brn-3c, which was not altered by the presence of TGF- $\beta 1$ for a further $24 \mathrm{hr}$ (Fig 2A). NF-160, a structural component of the neuronal cytoskeleton, was also undetectable in undifferentiated RGC-5 cells (Fig 2B), but was expressed by differentiated RGC-5 cells and was more than doubled in cells treated with TGF- $\beta 1$ (Fig 2B). Thy1.2, a cell surface glycoprotein of unknown function found predominantly in ganglion cells of the retina was detectable in non-differentiated RGC-5s (Fig. 2C and 2D) and increased over 2-fold after differentiation, but not by the addition of TGF- $\beta 1$. Tau, an axonal microtubule associated protein, also increased upon differentiation ( 7-fold) but not upon addition of TGF- $\beta 1$ (Fig. 2E). PGP9.5 (UCH-L1), a neuron-specific deubiquitinating enzyme, increased 2-fold after differentiation, and 3-fold upon incubation with TGF- $\beta 1$ for 24 hours (Fig. 2F).

\section{TGF- $\beta 1$ is a survival factor for RGC- 5 cells}

In order to assess the potential role for TGF- $\beta 1$ as a neuroprotectant for RGC- 5 cells, differentiated RGC-5 cells were incubated for $24 \mathrm{hr}$ in serum-free media in the presence or absence of $0.1 \mathrm{ng} / \mathrm{ml}$ TGF- $\beta 1$. FACs analysis using an Annexin V/propidium iodide (PI)based apoptotic assay revealed that the addition of $0.1 \mathrm{ng} / \mathrm{ml}$ TGF- $\beta 1$ reduced the level RGC-5 of apoptosis by $\sim 50 \%$ (Fig. 3A). In addition to Annexin V/PI detection of apoptosis, we examined cellular ATP metabolism as a surrogate for cell health. When compared to control cells, addition of TGF- $\beta 1$ to RGC-5 cells significantly increased ATP levels 7\% compared to control RGC-5 cells, demonstrating cellular metabolism was more active in the presence of TGF- $\beta 1$ (Fig. 3B).

\section{Intracellular smad and MAPK signaling in RGC-5 cells}

Intracellular smad and MAPK pathways have been reported to be involved in generating a TGF- $\beta 1$ signaling response either independently or simultaneously (Zavadil et al., 2001, Yu et al., 2002, Undevia et al., 2004, Valcourt et al., 2005, Yang et al., 2006). In order to determine the signaling pathway(s) that mediates TGF- $\beta 1$-induced differentiation of RGC-5, cells were treated for $24 \mathrm{hr}$ with $0.1 \mathrm{ng} / \mathrm{ml}$ TGF- $\beta 1$ and harvested for protein analysis of 
smad and MAPK signaling components. Western blot analysis revealed no change in the levels of $s m a d 2 / 3$ or smad1/5/8 or in their phosphorylation (Fig. 4).

We then examined whether MAPK pathways might be involved in TGF- $\beta 1$-induced RGC-5 differentiation by measuring the phosphorylation and total protein levels of ERK, JNK and p38. TGF- $\beta 1$ did not alter the phosphorylation or total protein levels of ERK or JNK (Fig. $5 \mathrm{~A}, \mathrm{~B})$. However, treatment with TGF- $\beta 1$ led to a 2 -fold increase in the phosphorylation of p38, while total p38 remained unchanged (Fig. 5C).

As MAPK, but not smad pathway components, were activated by TGF- $\beta 1$ treatment, we examined the role of MAPK signaling in TGF- $\beta 1$-induced RGC-5 differentiation. RGC-5 cells were treated with $0.5 \mu \mathrm{M}$ 3-(2-aminoethyl)-5-((4-ethoxyphenyl)methylene)-2,4thiazolidinedione, SP600125 or PD169316 for $24 \mathrm{hr}$ to inhibit ERK, JNK and p38, respectively. There was no change in TGF- $\beta 1$-induced neurite growth with ERK or JNK inhibition (Compare Fig. 6A with Fig. 6C and Fig. 6D). Inhibition of p38, however, blocked the effects of TGF- $\beta 1$-induced RGC-5 neurite outgrowth (Fig. 6B), demonstrating a requirement for $\mathrm{p} 38$ MAPK signaling in TGF- $\beta 1$-induced RGC-5 differentiation. The basal level of neurite outgrowth was unchanged with ERK (Compare Fig. 6A with Fig. 6C) or p38 inhibition (Compare Fig. 6A with Fig. 6B); however, inhibition of the JNK pathway led to an increase in neurite length in control (untreated RGC-5 cells) (Fig. 6A and Fig. 6D control), pointing to a role for JNK signaling in the regulation of neurite outgrowth.

\section{Discussion}

Previous reports indicate the presence of multiple components of the TGF- $\beta$ pathway in the developing retina, the adult retina and in cultured RGC (Yamanaka et al., 2002, Close et al., 2005, Ma et al., 2007). TGF- $\beta$ signaling is complex, with autocrine and paracrine signaling reported for multiple cell types and widespread detection of both receptor and ligand expression (Gordon-Thomson et al., 1998, Guérin et al., 2001, Close et al., 2005). Recent observations from studies of neuronal morphogenesis in the brain demonstrated that TGF- $\beta$ signaling is required for both axon formation and migration (Yi et al., 2010).

In addition to playing a role in neuronal structure and cell fate decisions, developmental studies reveal a potential role for TGF- $\beta 1$ as a neuroprotectant. Mice lacking TGF- $\beta 1$ exhibit a widespread increase in degeneration of neurons in the brain and prominent microgliosis prior to death (Brionne et al., 2003). Primary cultures of neurons from these mice display poor growth, possibly as a result of impaired TGF- $\beta 1$ regulation of apoptosis related genes (Brionne et al., 2003). Recent studies also demonstrate that Alzheimer's disease is associated with a decrease in circulating TGF- $\beta 1$ and an increase in sEng (Juraskova et al., 2010).

Motivated by these intriguing data and by the lack of studies in the retina, we sought to determine the effect of TGF- $\beta 1$ on differentiation and integrity of RGC- 5 cells. RGC- 5 cells have been widely used to examine RGC function in vitro (Das et al., 2006, Frassetto et al., 2006, Harvey and Chintala, 2007, Hong et al., 2007, Lieven et al., 2007, Krishnamoorthy et al., 2008, Tchedre et al., 2008a, Tchedre and Yorio, 2008) and a variety of treatments have been used to induce RGC-5 cell differentiation including the nonagglutinating lectin succinyl concanavalin A ( $\mathrm{SConA}$ ), and the nonselective protein kinase inhibitor staurosporine (Krishnamoorthy et al., 2001, Frassetto et al., 2006, Lieven et al., 2007, Wood et al., 2010). More recently, a method of differentiation using media conditioned by cultured ciliary epithelial cells has been reported (Tchedre et al., 2008b, Tchedre and Yorio, 2008). We have shown that adapting this method by using more sparsely seeded RGC- 5 cells and longer incubation times in $\mathrm{CM}$, leads to reproducible and robust RGC-5 cell differentiation, 
including growth arrest, neurite extension, and expression of the neuronal markers NF-160, Brn-3c, Thy1.2, Tau and PGP9.5.

Brn-3c, a transcription factor expressed predominantly by neuronal cells, is one of a number of markers that identifies the neuronal cell lineage. In vivo developmental studies have suggested a role for Brn-3c in promoting neurite outgrowth in differentiating RGCs in conjunction with Brn3b (Wang et al., 2002). Previous studies have failed to detect Brn-3c in cultured RGC-5 cells or in RGC-5 cells differentiated with either succinyl Concanavalin A, SS, or trichostatin A (Wood et al., 2010). Consistent with these observations, Brn-3c was not detectable in untreated RGC-5 cells but was expressed by cells differentiated in HNPEderived CM. Brn-3c is an early transcription factor involved in the induction of RGC differentiation, thus, it was not unexpected that TGF- $\beta 1$ did not alter Brn- $3 \mathrm{c}$ protein levels, as RGC- 5 cells are differentiated before TGF- $\beta 1$ is applied.

NF-160, a structural component of neurites, was increased in cells treated with TGF- $\beta 1$. Although the original characterization of the RGC-5 line reported the presence of neurofilament (Krishnamoorthy et al., 2001), more recent studies have failed to detect its presence in RGC-5 cells (Van Bergen et al., 2009, Wood et al., 2010). Similarly, neurofilament was not seen in RGC-5 cells prior to differentiation in CM, but was expressed by cells following differentiation and was significantly increased with the addition of TGF$\beta 1$. These findings suggest that although TGF- $\beta 1$ does not play a role in RGC-5 cell differentiation into a neuronal lineage, it does enhance the outgrowth of axonal structures of differentiated RGC-5 cells.

Thy 1, a marker of RGC, and Tau another protein of predominantly of neuronal origin, were both detectable in RGC-5 cells pre-differentiation and were increased after four days in CM. TGF- $\beta 1$ did not alter levels of Thy 1 or Tau in RGC- 5 cells. Furthermore, analysis of PGP9.5, the ubiquitin-protein hydrolase present in neuronal cell bodies, revealed an increase in expression with both differentiation and as well as with the addition of TGF- $\beta 1$. These findings demonstrate differentiation of RGC-5 cells in HNPE-CM leads to expression of multiple markers of neuronal cells and addition of TGF- $\beta 1$ further increases some of these markers, namely NF-160 and PGP9.5 to increase neuronal characteristics of these cells.

Formation of the tetrameric signaling complex of TGF- $\beta 1$ and TGF- $\beta$ receptors type I and II (TGF- $\beta$ RI, $-\beta$ RII) typically results in phosphorylation of the downstream transcription factors of smad2 and smad3 (Feng and Derynck, 2005). However, TGF- $\beta 1$ did not lead to a change in smad 2 or smad3 phosphorylation in RGC-5 cells. This finding led us to investigate the possible role of the MAPK signaling pathways, which have been shown to mediate TGF- $\beta 1$ signaling in some other cell types (Undevia et al., 2004, Horowitz et al., 2007, Yu et al., 2010) in the absence of smad signaling. Western blot analyses of differentiated RGC- 5 cells treated with TGF- $\beta 1$ revealed a significant increase in phosphorylation of p38, but not ERK or JNK. Furthermore, inhibition of p38, but not ERK or JNK, suppressed TGF- $\beta 1$ induction of neurite outgrowth, demonstrating that TGF- $\beta 1$ signaling occurs via 38 MAPK, and is independent of smad signaling in RGC- 5 cells. Smad-independent TGF- $\beta 1$ signaling similarly occurs via p38 signaling in epithelial and hepatocyte cell lines by inducing TRAF6 association with TGF $\beta$ receptors (Yamashita et al., 2008). A mutant TGF- $\beta$ receptor that retains 338 kinase activity, but is incapable of activating smads, was used to demonstrate smad-independent TGF- $\beta 1$ signaling via $\mathrm{p} 38$ in murine epithelial cells (Yu et al., 2002).

We have previously observed an increase in RGC apoptosis in mice in which TGF- $\beta$ was systemically neutralized by adenoviral expression of sEng (Walshe et al., 2009). These mice also exhibited significant retinal vascular dysfunction, perfusion abnormalities and 
permeability defects, but these experiments did not address if RGC apoptosis was due to the direct effect of TGF- $\beta 1$ on neural cells or if these effects were secondary to vascular dysfunction. To test whether TGF- $\beta 1$ is a survival factor for RGC-5s, the cells were exposed to TGF- $\beta 1$ under serum-free conditions for $24 \mathrm{hr}$. The administration of TGF- $\beta 1$ significantly reduced the level of apoptosis, demonstrating TGF- $\beta 1$ can indeed function as a survival factor for RGC-5 cells.

Consistent with these findings, mice lacking TGF- $\beta 1$ display extensive neural degeneration in the brain and are more susceptible to excitotoxic injury (Brionne et al., 2003). Similarly, overexpression of TGF- $\beta 1$ by astrocytes protects adult mice against neurodegeneration in an acute injury model (Brionne et al., 2003). In contrast to our observations, addition of TGF$\beta 1$ to developing retinal explants has been shown to induce ganglion cell apoptosis (Franke et al., 2006). These effects were more pronounced at embryonic (E) day 5 as compared to E11, suggesting that RGCs respond differently to TGF- $\beta 1$ depending upon retinal maturity. This difference may also be the result of the higher concentration of TGF- $\beta 1$ used in the latter study (20-fold higher than the current study).

Previous studies demonstrated a role for the TGF- $\beta$ family member bone morphogenetic proteins (BMPs) in neurite outgrowth and survival of primary cultures of RGCs; these studies also reported that TGF- $\beta 1$ did not influence RGC survival or differentiation (Kerrison et al., 2005). However, a very likely explanation for these discrepant results is the very high concentrations of TGF- $\beta 1(50 \mathrm{ng} / \mathrm{ml})$ used in these studies whereas our own finding demonstrate maximal effects on RGC at $0.1 \mathrm{ng} / \mathrm{ml}$. Interestingly, TGF- $\beta 1$ has been shown to display biphasic effects in other systems (Pepper et al., 1993). Moreover, observations in multiple cell types demonstrate that increasing growth factor concentration can lead to downregulation of the target receptor (Zhang et al., 2010).

The source of TGF- $\beta$ signaling in the retina is unclear. Müller cells in vitro release TGF- $\beta 1$ and thus may serve as a source of TGF- $\beta 1$ for RGC in vivo (Abukawa et al., 2009). Both vascular endothelial and mural cells, which comprise the inner vascular plexus within the ganglion cell layer, are known to synthesize TGF- $\beta 1$ (Hirschi et al., 1998, Ding et al., 2004). Astrocytes, which are abundant in the retina and in close proximity to the RGCs, also synthesize TGF- $\beta 1$ (Dhandapani et al., 2003). Lastly, RGCs themselves synthesize TGF- $\beta 1$ (Gordon-Thomson et al., 1998), raising the possibility of an autocrine role for TGF- $\beta 1$ in vivo. Taken together, these studies describe an important role for TGF- $\beta 1$ signaling in differentiated RGCs and point to a potential therapeutic role for TGF- $\beta 1$ in neuroprotection.

\section{Acknowledgments}

The authors thank Drs. Magali Saint-Geniez, Bertin Tchedre, Anson Cho and Tom Yorio for helpful discussions and for providing valuable reagents. This work was supported by EY05318 (PD'A) and by the Core grant for Vision Research P30EY14104 (PD'A) and Knights Templar Eye Foundation award (TEW).

\section{Glossary of terms}

$\begin{array}{ll}\text { RGC } & \text { retinal ganglion cell } \\ \text { HNPE } & \text { human non-pigmented ciliary epithelial cells } \\ \text { CM } & \text { conditioned media } \\ \text { SEng } & \text { soluble endoglin } \\ \text { ERG } & \text { electroretinogram }\end{array}$




\section{References}

Abukawa H, Tomi M, Kiyokawa J, Hori S, Kondo T, Terasaki T, Hosoya K. Modulation of retinal capillary endothelial cells by Müller glial cell-derived factors. Mol Vis. 2009; 15:451-457. [PubMed: 19247458]

Bode SF, Jehle T, Bach M. Pattern electroretinogram (PERG) in glaucoma suspects -- new findings from a longitudinal study. Invest Ophthalmol Vis Sci. 2011

Brionne TC, Tesseur I, Masliah E, Wyss-Coray T. Loss of TGF-beta 1 leads to increased neuronal cell death and microgliosis in mouse brain. Neuron. 2003; 40:1133-1145. [PubMed: 14687548]

Close JL, Gumuscu B, Reh TA. Retinal neurons regulate proliferation of postnatal progenitors and Müller glia in the rat retina via TGF beta signaling. Development. 2005; 132:3015-3026. [PubMed: 15944186]

Das A, Garner DP, Del Re AM, Woodward JJ, Kumar DM, Agarwal N, Banik NL, Ray SK. Calpeptin provides functional neuroprotection to rat retinal ganglion cells following $\mathrm{Ca} 2+$ influx. Brain Research. 2006; 1084:146-157. [PubMed: 16600192]

Dhandapani KM, Hadman M, De Sevilla L, Wade MF, Mahesh VB, Brann DW. Astrocyte protection of neurons: role of transforming growth factor-beta signaling via a c-Jun-AP-1 protective pathway. $\mathrm{J}$ Biol Chem. 2003; 278:43329-43339. [PubMed: 12888549]

Ding R, Darland DC, Parmacek MS, D' Amore PA. Endothelial-mesenchymal interactions in vitro reveal molecular mechanisms of smooth muscle/pericyte differentiation. Stem cells and development. 2004; 13:509-520. [PubMed: 15588508]

Downs JC, Roberts MD, Burgoyne CF. Mechanical environment of the optic nerve head in glaucoma. Optom Vis Sci. 2008; 85:425-435. [PubMed: 18521012]

Du J, Bernasconi P, Clauser KR, Mani DR, Finn SP, Beroukhim R, Burns M, Julian B, Peng XP, Hieronymus H, Maglathlin RL, Lewis TA, Liau LM, Nghiemphu P, Mellinghoff IK, Louis DN, Loda M, Carr SA, Kung AL, Golub TR. Bead-based profiling of tyrosine kinase phosphorylation identifies SRC as a potential target for glioblastoma therapy. Nat Biotechnol. 2009; 27:77-83. [PubMed: 19098899]

Endo Y, Beauchamp E, Woods D, Taylor WG, Toretsky JA, Uren A, Rubin JS. Wnt-3a and Dickkopf-1 stimulate neurite outgrowth in Ewing tumor cells via a Frizzled3- and c-Jun Nterminal kinase-dependent mechanism. Mol Cell Biol. 2008; 28:2368-2379. [PubMed: 18212053]

Feng XH, Derynck R. Specificity and versatility in tgf-beta signaling through Smads. Annu Rev Cell Dev Biol. 2005; 21:659-693. [PubMed: 16212511]

Franke A, Gubbe C, Beier M, Duenker N. Transforming growth factor-beta and bone morphogenetic proteins: cooperative players in chick and murine programmed retinal cell death. J Comp Neurol. 2006; 495:263-278. [PubMed: 16440295]

Frassetto LJ, Schlieve CR, Lieven CJ, Utter AA, Jones MV, Agarwal N, Levin LA. Kinase-dependent differentiation of a retinal ganglion cell precursor. Investigative Ophthalmology \& Visual Science. 2006; 47:427-438. [PubMed: 16384993]

Goldberg PL, MacNaughton DE, Clements RT, Minnear FL, Vincent PA. p38 MAPK activation by TGF-beta1 increases MLC phosphorylation and endothelial monolayer permeability. Am J Physiol Lung Cell Mol Physiol. 2002; 282:L146-154. [PubMed: 11741826]

Gordon-Thomson C, de Iongh RU, Hales AM, Chamberlain CG, McAvoy JW. Differential cataractogenic potency of TGF-beta1, -beta2, and -beta3 and their expression in the postnatal rat eye. Investigative Ophthalmology \& Visual Science. 1998; 39:1399-1409. [PubMed: 9660488]

Green AJ, McQuaid S, Hauser SL, Allen IV, Lyness R. Ocular pathology in multiple sclerosis: retinal atrophy and inflammation irrespective of disease duration. Brain. 2010; 133:1591-1601. [PubMed: 20410146]

Guérin CJ, Hu L, Scicli G, Scicli AG. Transforming growth factor beta in experimentally detached retina and periretinal membranes. Experimental Eye Research. 2001; 73:753-764. [PubMed: 11846507]

Harvey R, Chintala SK. Inhibition of plasminogen activators attenuates the death of differentiated retinal ganglion cells and stabilizes their neurite network in vitro. Investigative Ophthalmology \& Visual Science. 2007; 48:1884-1891. [PubMed: 17389524] 
Hirschi KK, Rohovsky SA, D’Amore PA. PDGF, TGF-beta, and heterotypic cell-cell interactions mediate endothelial cell-induced recruitment of 10T1/2 cells and their differentiation to a smooth muscle fate. J Cell Biol. 1998; 141:805-814. [PubMed: 9566978]

Hong S, Lee JE, Kim CY, Seong G. Agmatine protects retinal ganglion cells from hypoxia-induced apoptosis in transformed rat retinal ganglion cell line. BMC Neurosci. 2007; 8:81. [PubMed: 17908330]

Horowitz JC, Rogers DS, Sharma V, Vittal R, White ES, Cui Z, Thannickal VJ. Combinatorial activation of FAK and AKT by transforming growth factor-betal confers an anoikis-resistant phenotype to myofibroblasts. Cell Signal. 2007; 19:761-771. [PubMed: 17113264]

Juraskova B, Andrys C, Holmerova I, Solichova D, Hrnciarikova D, Vankova H, Vasatko T, Krejsek J. Transforming Growth Factor Beta and Soluble Endoglin in the Healthy Senior and in Alzheimer's Disease Patients. The journal of nutrition, health \& aging. 2010; 14:758-761.

Kerrison JB, Lewis RN, Otteson DC, Zack DJ. Bone morphogenetic proteins promote neurite outgrowth in retinal ganglion cells. Mol Vis. 2005; 11:208-215. [PubMed: 15788999]

Krishnamoorthy R, Rao V, Dauphin R, Prasanna G, Johnson C, Yorio T. Role of the ETB receptor in retinal ganglion cell death in glaucoma. Can J Physiol Pharmacol. 2008; 86:380-393. [PubMed: 18516102]

Krishnamoorthy RR, Agarwal P, Prasanna G, Vopat K, Lambert W, Sheedlo HJ, Pang IH, Shade D, Wordinger RJ, Yorio T, Clark AF, Agarwal N. Characterization of a transformed rat retinal ganglion cell line. Brain Res Mol Brain Res. 2001; 86:1-12. [PubMed: 11165366]

Laketa V, Simpson JC, Bechtel S, Wiemann S, Pepperkok R. High-content microscopy identifies new neurite outgrowth regulators. Mol Biol Cell. 2007; 18:242-252. [PubMed: 17093056]

Lieven CJ, Millet LE, Hoegger MJ, Levin LA. Induction of axon and dendrite formation during early RGC-5 cell differentiation. Experimental Eye Research. 2007; 85:678-683. [PubMed: 17904550]

Ma L, Cantrup R, Varrault A, Colak D, Klenin N, Gotz M, McFarlane S, Journot L, Schuurmans C. Zac1 functions through TGFbetaII to negatively regulate cell number in the developing retina. Neural Develop. 2007; 2:11.

Pepper MS, Vassalli JD, Orci L, Montesano R. Biphasic effect of transforming growth factor-beta 1 on in vitro angiogenesis. Experimental Cell Research. 1993; 204:356-363. [PubMed: 7679998]

Rodríguez-Barbero A, Obreo J, Alvarez-Munoz P, Pandiella A, Bernabéu C, López-Novoa JM. Endoglin modulation of TGF-beta1-induced collagen synthesis is dependent on ERK1/2 MAPK activation. Cell Physiol Biochem. 2006; 18:135-142. [PubMed: 16914898]

Tchedre K, Huang R, Dibas A, Krishnamoorthy R, Dillon G, Yorio T. Sigma-1 receptor regulation of voltage-gated calcium channels involves a direct interaction between sigma-1 receptors and the voltage-gated L-type calcium channel. Investigative Ophthalmology \& Visual Science. 2008a

Tchedre KT, Huang RQ, Dibas A, Krishnamoorthy RR, Dillon GH, Yorio T. Sigma-1 receptor regulation of voltage-gated calcium channels involves a direct interaction between sigma-1 receptors and the voltage-gated L-type calcium channel. Investigative Ophthalmology \& Visual Science. $2008 \mathrm{~b}$

Tchedre KT, Yorio T. sigma-1 receptors protect RGC-5 cells from apoptosis by regulating intracellular calcium, Bax levels, and caspase-3 activation. Investigative Ophthalmology \& Visual Science. 2008; 49:2577-2588. [PubMed: 18296662]

Undevia NS, Dorscheid DR, Marroquin BA, Gugliotta WL, Tse R, White SR. Smad and p38-MAPK signaling mediates apoptotic effects of transforming growth factor-beta1 in human airway epithelial cells. Am J Physiol Lung Cell Mol Physiol. 2004; 287:L515-524. [PubMed: 15132952]

Valcourt U, Kowanetz M, Niimi H, Heldin C-H, Moustakas A. TGF-beta and the Smad signaling pathway support transcriptomic reprogramming during epithelial-mesenchymal cell transition. Mol Biol Cell. 2005; 16:1987-2002. [PubMed: 15689496]

Van Bergen NJ, Wood JPM, Chidlow G, Trounce IA, Casson RJ, Ju W-K, Weinreb RN, Crowston JG. Recharacterization of the RGC-5 retinal ganglion cell line. Investigative Ophthalmology \& Visual Science. 2009; 50:4267-4272. [PubMed: 19443730]

Walshe T, Saint-Geniez M, Maharaj AS, Sekiyama E, Maldonado A, D' Amore PA. TGF-beta is required for vascular barrier function, endothelial survival and homeostasis of the adult microvasculature. PLoS ONE. 2009; 4:e5149. [PubMed: 19340291] 
Wang SW, Mu X, Bowers WJ, Kim D-S, Plas DJ, Crair MC, Federoff HJ, Gan L, Klein WH. Brn3b/ Brn3c double knockout mice reveal an unsuspected role for Brn3c in retinal ganglion cell axon outgrowth. Development. 2002; 129:467-477. [PubMed: 11807038]

Watanabe H, de Caestecker MP, Yamada Y. Transcriptional cross-talk between Smad, ERK1/2, and p38 mitogen-activated protein kinase pathways regulates transforming growth factor-beta-induced aggrecan gene expression in chondrogenic ATDC5 cells. J Biol Chem. 2001; 276:14466-14473. [PubMed: 11278290]

Wood JPM, Chidlow G, Tran T, Crowston JG, Casson RJ. A comparison of differentiation protocols for RGC-5 cells. Investigative Ophthalmology \& Visual Science. 2010; 51:3774-3783. [PubMed: 20181845]

Yamanaka R, Ogata N, Yamamoto C, Matsushita M, Matsuzaki K, Uyama M, Matsumura M. Expression of transforming growth factor-beta receptors in normal rat retina and experimental choroidal neovascularization. Jpn J Ophthalmol. 2002; 46:525-532. [PubMed: 12457911]

Yamashita M, Fatyol K, Jin C, Wang X, Liu Z, Zhang YE. TRAF6 mediates Smad-independent activation of JNK and p38 by TGF-beta. Mol Cell. 2008; 31:918-924. [PubMed: 18922473]

Yang W, Chen Y, Zhang Y, Wang X, Yang N, Zhu D. Extracellular signal-regulated kinase 1/2 mitogen-activated protein kinase pathway is involved in myostatin-regulated differentiation repression. Cancer Res. 2006; 66:1320-1326. [PubMed: 16452185]

Yi JJ, Barnes AP, Hand R, Polleux F, Ehlers MD. TGF-beta signaling specifies axons during brain development. Cell. 2010; 142:144-157. [PubMed: 20603020]

Yu H-W, Liu Q-F, Liu G-N. Positive regulation of the Egr-1/osteopontin positive feedback loop in rat vascular smooth muscle cells by TGF-beta, ERK, JNK, and p38 MAPK signaling. Biochemical and biophysical research communications. 2010

Yu L, Hébert MC, Zhang YE. TGF-beta receptor-activated p38 MAP kinase mediates Smadindependent TGF-beta responses. EMBO J. 2002; 21:3749-3759. [PubMed: 12110587]

Zavadil J, Bitzer M, Liang D, Yang YC, Massimi A, Kneitz S, Piek E, Bottinger EP. Genetic programs of epithelial cell plasticity directed by transforming growth factor-beta. Proc Natl Acad Sci USA. 2001; 98:6686-6691. [PubMed: 11390996]

Zhang Z, Neiva KG, Lingen MW, Ellis LM, Nör JE. VEGF-dependent tumor angiogenesis requires inverse and reciprocal regulation of VEGFR1 and VEGFR2. Cell Death Differ. 2010; 17:499-512. [PubMed: 19834490] 


\section{Research Highlights}

- We examine retinal ganglion cell neuroprotection with TGF- $\beta 1$

- TGF- $\beta 1$ maintains health of retinal ganglion cells

- TGF- $\beta 1$ enhances neurite length and neuronal differentiation

- $\quad$ TGF- $\beta 1$ effects these changes via phosphorylation of p38 MAPK 

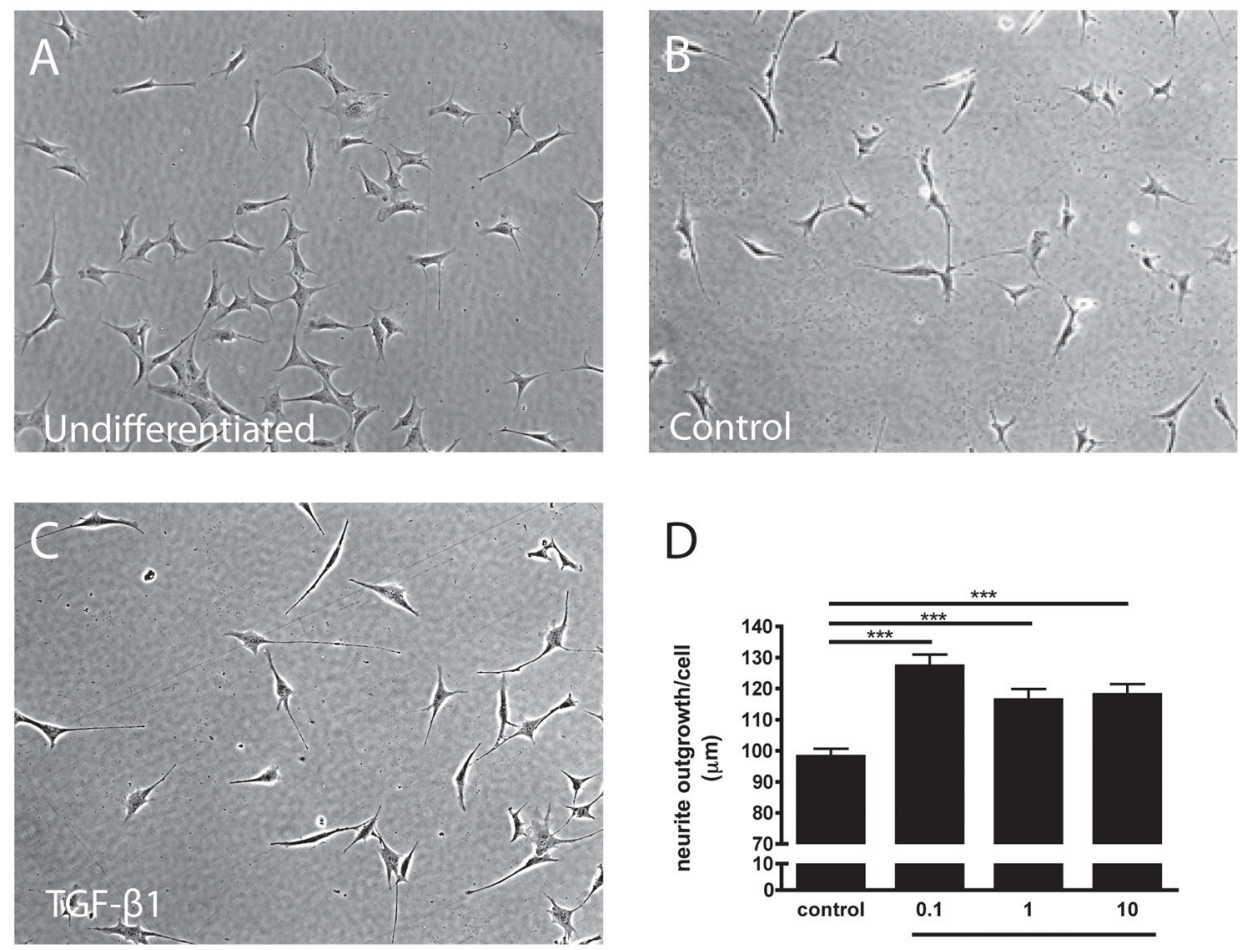

D

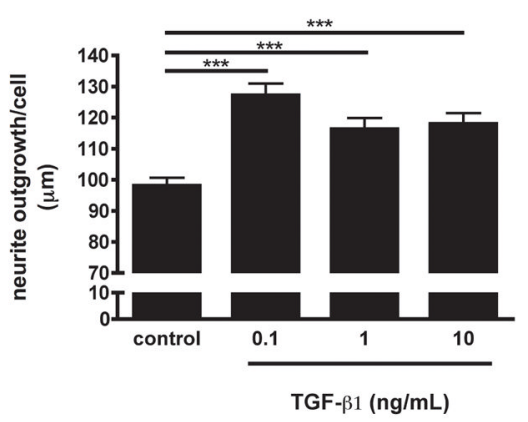

Figure 1. Effect of TGF- $\beta 1$ on RGC-5 cell differentiation

(A) Undifferentiated RGC-5 cells; (B) RGC-5 cells differentiated in HNPE cell CM for four days; (C) Differentiated RGC-5 cells treated with $0.1 \mathrm{ng} / \mathrm{ml} \mathrm{TGF-} \beta 1$ induces neurite extension. (D) Addition of TGF- $\beta 1$ increases neurite length, with the maximal effect at 0.1 $\mathrm{ng} / \mathrm{ml}$ TGF- $\beta 1 . * * * \mathrm{p}<0.0001$ 


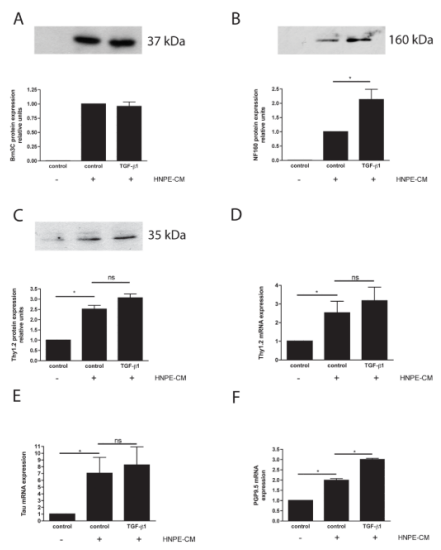

Figure 2. Effect of TGF- $\beta 1$ on expression of neuronal-specific markers by RGC-5 cells Western blot analysis for: (A) Brn-3c, (B) NF-160 and (C) Thy 1.2 and realtime-PCR for: (D) Thy 1.2, (E) Tau and (F) PGP9.5. Brn-3c and NF-160 were not detected in undifferentiated RGC- 5 but were expressed by differentiated RGC-5. Thy 1.2 was present in undifferentiated RGC-5s and increased after differentiation. Differentiation increased expression of Thy 1.2, Tau and PGP9.5. Addition of TGF- $\beta 1$ to differentiated RGC-5 cells increased NF-160, but not Brn-3c or Thy1.2 protein and increased PGP9.5, but not (D) Thy 1.2 or (E) Tau mRNA. $\mathrm{N}=3$; ${ }^{*} \mathrm{p}<0.05$ 
A

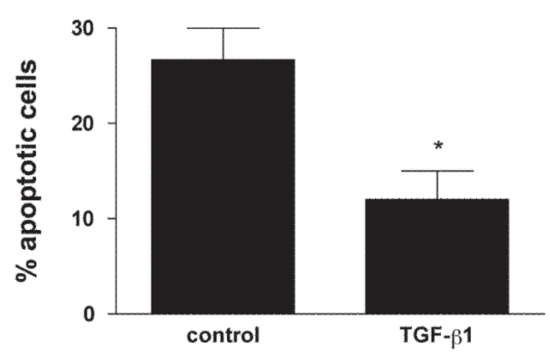

B

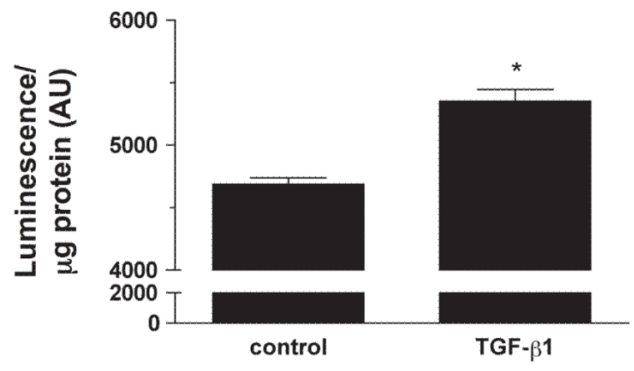

Figure 3. Effect of TGF-p1 on RGC-5 cell apoptosis

(A) Annexin V/Propidium iodide analysis of apoptosis by of differentiated RGC-5 cells cultured in serum-free medium in the presence or absence of TGF- $\beta 1$ for $24 \mathrm{hr}$ led to a significant decrease in apoptosis with TGF- $\beta 1$. (B) TGF- $\beta 1$ treatment increased RGC-5 cellular metabolism as evidenced by levels of ATP. $\mathrm{N}=3 ;{ }^{*} \mathrm{p}<0.05$ 


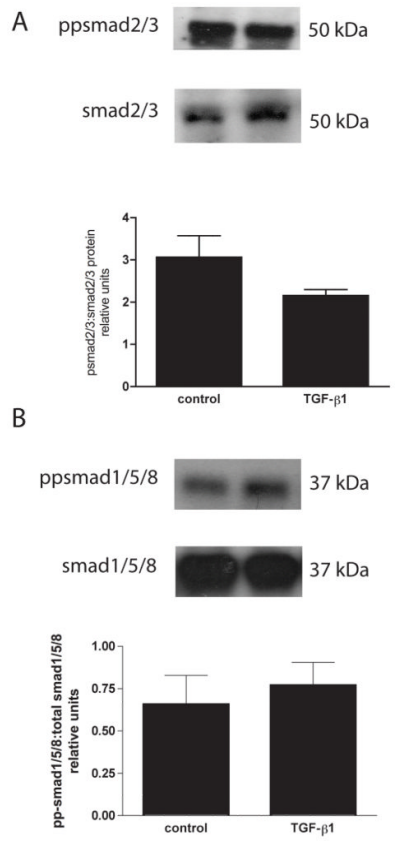

Figure 4. Effect of TGF- $\beta 1$ on smad signaling in RGC-5

(A) Western blot analysis of (A) phospho-smad2/3, total-smad2/3 and (B) phosphosmad1/5/8 and total smad1/5/8 revealed no significant changes. $\mathrm{N}=3$. 


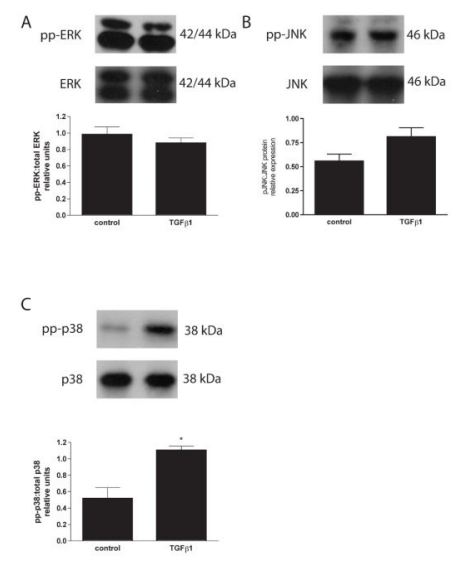

Figure 5. Role of ERK, JNK and p38 MAPK in TGF- $\beta 1$ signaling in differentiated RGC-5 cells (A) Western blot analysis of phospho-ERK, total-ERK, (B) phospho-JNK and total JNK revealed no significant changes. (C) Addition of TGF- $\beta 1$ increased phospho-p38, with no changes in total $\mathrm{p} 38 . \mathrm{N}=3 ;{ }^{*} \mathrm{p}<0.05$ 


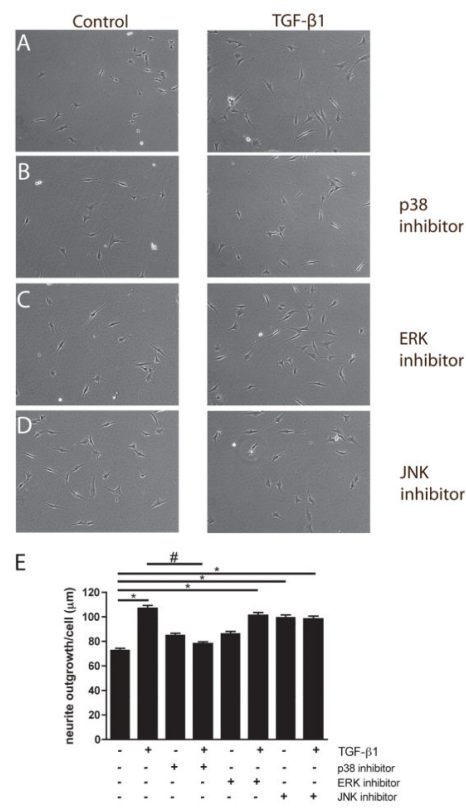

Figure 6. Role of p38 MAPK, ERK and JNK MAPK in TGF- $\beta 1$-induced differentiated RGC-5 cell neurite outgrowth

Cells were differentiated, and treated with TGF- $\beta 1$ in the presence or absence of: (A) no inhibitors; (B) the p38 inhibitor (PD169316); (C) the ERK inhibitor (3-(2-aminoethyl)-5-((4ethoxyphenyl)methylene)-2,4-thiazolidinedione hydrochloride); or (D) the JNK inhibitor, SP600125. (E) Neurites were quantified as described in the methods. p38, but not ERK or JNK MAPK, mediates the effects of TGF- $\beta 1$ on RGC- 5 cell neurite outgrowth. $\mathrm{N}=3$; $* \mathrm{p}<0.01$ compared to control; \# $\mathrm{p}<0.01$ compared to TGF- $\beta 1$ control. 